\title{
ANALISA KERUSAKAN PIPA PEMANAS AIR UNTUK UAP PEMBANGKIT LISTRIK FAILURE ANALYSIS OF WATER HEATER PIPE FOR STEAM GENERATOR
}

\author{
Sutarjo ${ }^{\text {a) }}$,M. Syahril ${ }^{\text {b) }}$ \\ Balai Besar Teknologi Kekuatan Struktur - BPPT \\ Kawasan PUSPIPTEK Gd. 220 Serpong ,Tangerang 15314 \\ e-mail:sutarjodurahman@yahoo.com,msyahrilluk@yahoo.com
}

Tanggal masuk naskah : 18/07/2014 ; Tanggal revisi: 19/09/2014 ; Tanggal persetujuan cetak : 08/10/2014

\begin{abstract}
Abstrak
Pipa heater digunakan sebagai media untuk memanaskan fluida atau untuk merubah fase dari cair menjadi uap/gas. Pecahnya pipa dapat menyebabkan semua sistim dalam proses produksi akan menjadi berhenti dan potensi kerugian secara ekonomi tinggi. Penelitian ini bertujuan untuk menghindari kasus kerusakan yang serupa dimasa mendatang.

Pemeriksaan visual, makrografi, struktur mikro, uji kekerasan dan pemeriksaan SEM dan EDAX merupakan metode yang diterapkan dalam penelitian ini. Diketahui bahwa pipa pecah pada area jam 6,nilai kekerasan yang identik dengan kekuatan tarik material (476 MPa) masih di atas standar spesifikasi dan indikasi yang sama juga ditunjukkan dari struktur mikro yaitu fase ferit - pearlit normal. Dengan suhu sekitar 390 C dan jejak penipisan dinding di sekitar 4:30-7:30, sehingga pecahnya pipa karena dinding tipis tidak bisa menahan tekanan dalam pipa dan penipisan terjadi disebabkan air tingkat di pemanas pipa terlalu rendah, sehingga mengakibatkan kavitasi gelembung uap pada permukaan dalam dinding pipa.
\end{abstract}

Kata Kunci : Pipa, pecah, dinding tipis, tingkat-air, temperatur, kapitasi.

\begin{abstract}
Abstrack
Heater's pipes are used as a media for heating of fluids or changing of their of phase from liquid to vapor/gas. Rupture of these pipes may cause all systems in the production process stopand the high economic losses. This study aims to avoid the cases to accur in the future.

Visual inspection, macrography, microstructure, hardness test and SEM-EDAX examination were the methods applied in this study. It was known that the pipe ruptured atthe 6 o'clock area, the hardness value of which was identical to the material tensile strength (476 MPa), conforming to the standard specification and the same indication was also indicated from the microstructure of the normal ferrite-pearlite phase. At atemperature of about $390 \mathrm{C}$ and traces of wall thinning in around 4:30 to 7:30, the pipes ruptured due to the thin walls could not withstand the internal pressure of the pipe. The thinking occurred because the water-level in the heater's pipes was to low,resulting in cavitation of vapor bubbles on the inside surface of pipe wall.
\end{abstract}

Keywords: Pipe, rupture, thin-wall, water-level, temperature, cavitation.

\section{PENDAHULUAN}

Peralatan industri-industri proses seperti industri pengolahan minyak, industri kimia dan pembangkit tenaga listrik yang telah dioperasikan dalam kurun waktu yang cukup lama. Pada industri-industri tersebut banyak diketemukan komponen-komponen yang dioperasikan pada suhu cukup tinggi yang tentunya harus dioperasikan dengan aman karena kecelakaan pada industriindustri tersebut akan berakibat kerugian yangbesar ${ }^{(1)}$. 
Pipa merupakan salah satu komponen konstruksi yang selalu digunakan untuk berbagai keperluan industri, terutama pabrik (plan) yang berfungsi sebagai transportasi aliran fluida dari satu area ke area lainnya dan dapat juga dipakai sebagai komponen untuk perpindahan panas seperti pada heater, reaktor, ketel uap dan lainnya.

Saat dilakukan pabrikasi biasanya faktorfaktor seperti material, kondisi operasi yang berupa tekanan dan temperatur operasi, lingkungan atau media yang akan mengalir, dan lain sebagainya telah diperhitungkan sedemikian rupa, sehingga diperoleh spesifikasi material yang akan digunakan dalam pabrikasi dan juga perkiraan umur pemakaian material.

Pada kenyataannya, kerusakan suatu instalasi pipa pada saat plan beroperasi masih banyak ditemukan.Kerusakan dari material instalasi pipa dalam aplikasi dapat disebabkan oleh beberapa faktor berikut ini $^{(2)}$ :Faktor design meliputi bentuk, design takikan, lokasi sambungan atau lasan dan konfigurasinya.

- Material yang meliputi pemilihan material, transportasi material pipa dari suatu tempat ketempat lainnya dan material elektroda las yang digunakan tidak sesuai dengan spesifikasinya.

- Cacat material meliputi cacat yang dihasilkan pada saat pabrikasi, cacat yang ditimbulkan akibat pembentukan pelat atau pipa dan lain-lain.

- Pabrikasi meliputi pembentukan, pengelasan, perlakuan panas (heat treatment), pembersihan saat pabrikasi.

- Operasi atau pemakaian meliputi kondisi operasi yang berlebihan (excessively severe service condition).

Adapun jenis-jenis kegagalan / kerusakan yang terjadi pada material pipa setelah dioperasikan diantaranya adalah korosi, erosi, fatik, overload dan lain sebagainya.

Salah satu kasus kerusakan pipa ataupipa yang pernah terjadi adalah kerusakan atau kegagalan dari material pipa heater untuk steam generatorpada saat dioperasikan. Karena kasus tersebut telah menyebabkan terhentinya pengoperasian dan proses yang berhubungan langsung secara keseluruhan dengan heater tersebut, maka dianggap perlu untuk dilakukan suatu investigasi atau pengkajian mengenai penyebabkan kegagalan / kerusakan material pipa. Dengan demikian, diharapkan kerusakan yang sama dikemudian hari dapat dihindari.

\subsection{Data Teknis}

Adapun kondisi operasi dari pipa heateradalah sebagai berikut :

Komponen : Pipaheater

Material : ASTM SA 106 Grade B

Tekanan Operasi : $80 \mathrm{~kg} / \mathrm{cm} 2$

Temperatur flue gas: $395 \mathrm{C}$

Fungsi

: Steam generator

\subsection{Informasi Teknis}

Pipaheaterdiketahui telah mengalami kebocoran / kerusakan di posisi jam 6 pada pipa bagian bawah yaitu pipa yang berhadapan langsung dengan sumber panas. Sumber panas berasal dari burner yang terpasang di bagian bawah heater sehingga aliran panas di mulai dari bawah yaitu pipa yang berfungsi memanaskan minyak mentah dengan posisi susunan pipa vertikal (radiant pipa) menuju ke areabagian atas yaitu pipa yang berfungsi sebagai pemanas air untuk steam generator dengan posisi susunan horizontal (convection pipe) $)^{(3)}$, seperti terlihat pada gambar 1 berikut ini.

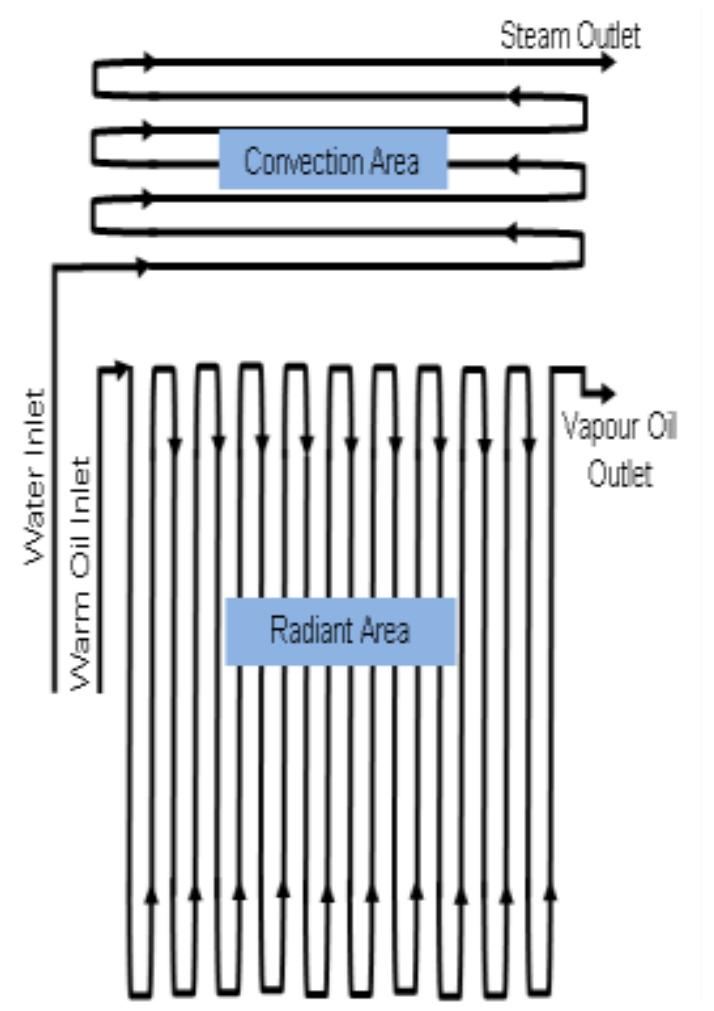

Gambar 1a : llustrasi skema susunan pipa heater 


\section{BAHAN DAN METODA}

\subsection{Bahan Penelitian}

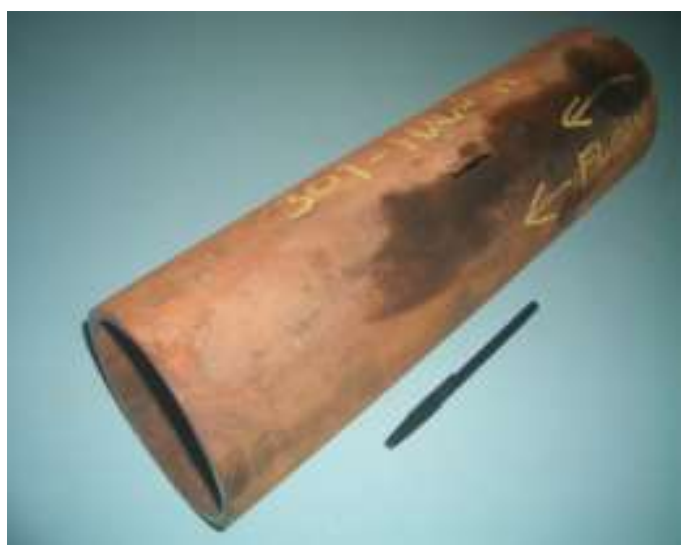

Gambar 1b : Foto potongan pipa pemanas air yang rusak.

Bahan yang menjadi fokus peneltian adalah potongan dari pipa (gambar 1) yang merupakan bagian dari pipa pemanas air (water heater) untuk pembangkit listrik tenaga uap (steam generator) yang telah mengalami kerusakan seperti terlihat pada gambar 1 berikut.

\subsection{Metoda Penelitian}

\section{Kegiatan penelitian terhadap pipa yang rusak dilakukan dengan menggunakan aliran proses seperti terlihat pada gambar 2 berikut ini.}

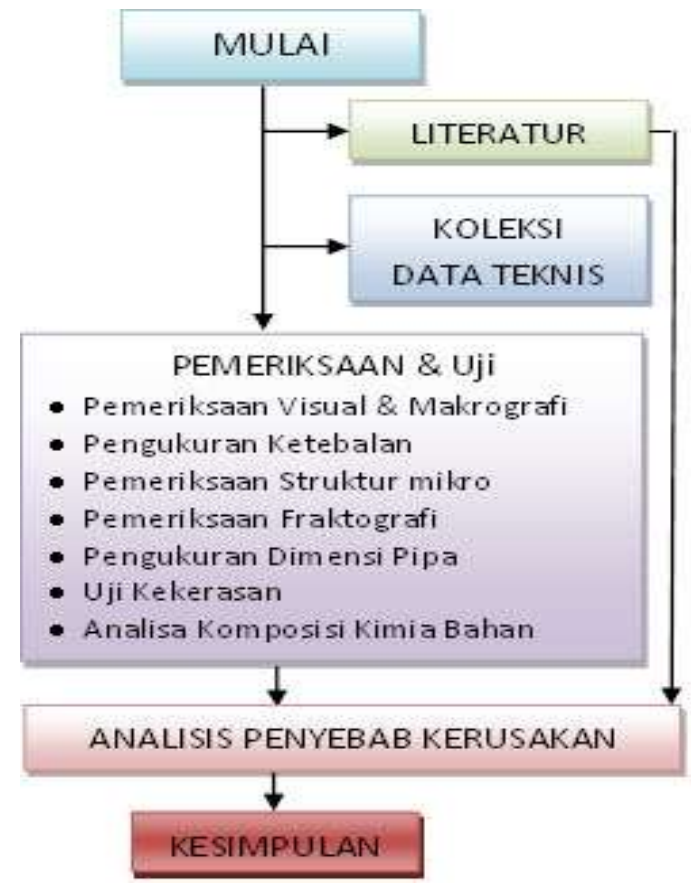

Gambar 2 : Diagram alir penelitian.

\section{a) Analisa Komposisi Kimia}

Untuk melihat unsur-unsur yang terkandung di dalam material pipa dan membandingnya dengan komposisi spesifikasi acuan, maka dilakukan pemeriksaan / analisa komposisi kimia material / bahan pipa dengan menggunakan peralatan spark spectrometer.

\section{b) Pemeriksaan Visual}

Pemeriksaan visual dilakukan untuk mengidentifikasi karakteristik kerusakan dan menentukan langkah persiapan untuk peme-riksaan selanjutnya.Metoda pemeriksaan visual ini dilakukan dengan mengamati kondisi sampel secara cermat, seperti lokasi-lokasi yang mengalami kerusakan dan kemudian di lakukan dokumentasi dengan kamera.

\section{c) Pemeriksaan Mikrografi}

Pemeriksaan secara mikrografi (metalografi) merupakan suatu metoda pemeriksaan yang dilakukan untuk mengamati lebih rinci pada beberapa area yang dianggap mewakili untuk melakukan analisis yang mendalam mengenai penyebab kerusakan dari Auxiliary pipa heater tersebut, seperti kondisi struktur mikro dan perubahannya, cacat struktur, karakteristik permukaan pecah / retakan.

Peralatan yang digunakan dalam pemeriksaan ini adalah :

- Alat potong untuk sample.

- Grinding polishing.

- Mikroskop.

- Kamera digital.

\section{d) Uji Kekerasan}

Uji kekerasan dilakukan untuk mengetahui perbedaan nilai kekerasan di area yang dianngap normal dengan area disekitar pecah / retakan. Pengujian kekerasan dilakukan dengan alat Frank fino test yang dikonversikan ke dalam nilai HB (hardness Brinnel).

\section{e) Analisa SEM - EDAX}

Untuk melihat lebih rinci kondisi permukaan pecah / retakan secara fraktografi dan mengetahui kandungan unsur-unsur yang bersifat agresif (di dalam produk korosi) yang mempromosikan terhadap terjadinya kerusakan. 


\section{HASIL DAN PEMBAHASAN}

\subsection{Hasil Penelitian}

\section{A.Analisa komposisi kimia.}

Hasil analisa komposisi kimia (tabel 4) mengindikasikan bahwa jenis material pipa adalah baja karbon ${ }^{(4)}$ (Carbon steel).

Tabel 4. Analisa komposisi kimia material.

\begin{tabular}{cccc}
\hline \multicolumn{4}{c}{ Hasil Analisa } \\
\hline Unsur & $\%$ berat & Unsur & \% berat \\
\hline $\mathrm{Fe}$ & 98.98 & $\mathrm{Mo}$ & 0.0018 \\
$\mathrm{C}$ & 0.20 & $\mathrm{Cu}$ & 0.013 \\
$\mathrm{Si}$ & 0.22 & $\mathrm{~V}$ & 0.021 \\
$\mathrm{Mn}$ & 0.59 & $\mathrm{~W}$ & 0.019 \\
$\mathrm{Cr}$ & 0.011 & $\mathrm{~S}$ & 0.016 \\
$\mathrm{Ni}$ & 0.018 & $\mathrm{P}$ & 0.033 \\
\hline
\end{tabular}

\section{B. Pemeriksaan visual dan Makrografi.}

Berdasarkan hasil dari pemeriksaan visual terhadap kerusakan pipa (lihat gambar $2 \mathrm{~s} / \mathrm{d}$ 5) menunjukkan bahwa di sepanjang dinding pipa bagian dalam (inside diameter) terlihat adanya penipisan cukup signifikan yang terjadi di sekitar area jam $4^{.30}$ hingga jam $7^{.30}$ dan penipisan yang sangat signifikan terjadi di area jam 6 yang merupakan area pipa yang pecah/robek. Selain itu, di area pecah juga terlihat adanya jejak yang berupa perubahan warna yaitu dari kemerahan menjadi lebih hitam.

Pemeriksaan secara makro menunjukkan bahwa pada permukaan pipa yang pecah tidak mengindikasikan adanya deformasi plastik yang cukup signifikan ${ }^{(5)}$ dan ujung pecah dari pipa terlihat cukup tajam.

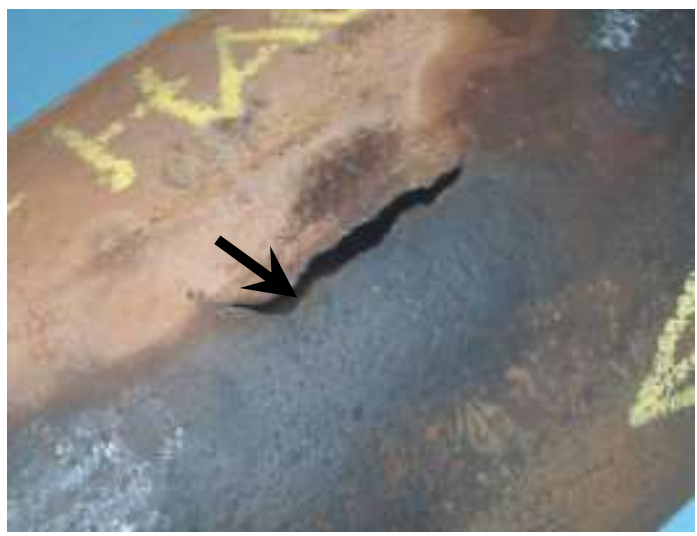

Gambar 2 : Foto kondisi visual area pecahnya material pipa heatermenunjukkan bahwa area permukaan pecah tidak terjadi deformasi plastik yang cukup signifikan.

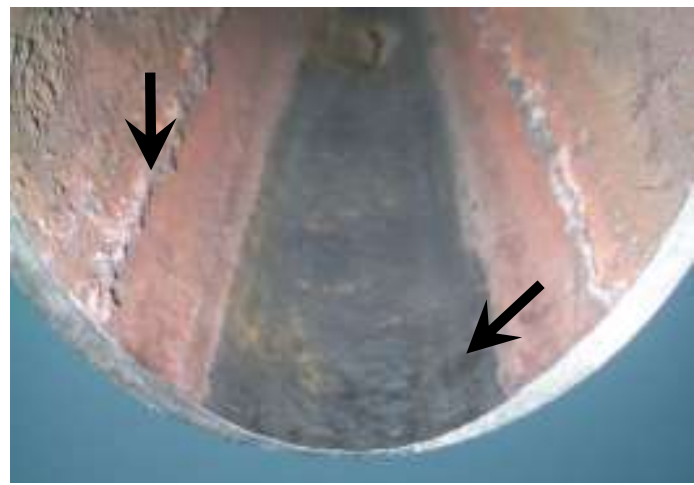

Gambar 3 : Foto kondisi visual permukaan dalam pipa heater menunjukkan bahwa penipisan pipa terjadi di area jam $4 .^{30}-7 .^{30}$ (tanda panah) dan pada jam $5 .{ }^{15}-6 .{ }^{45}$.

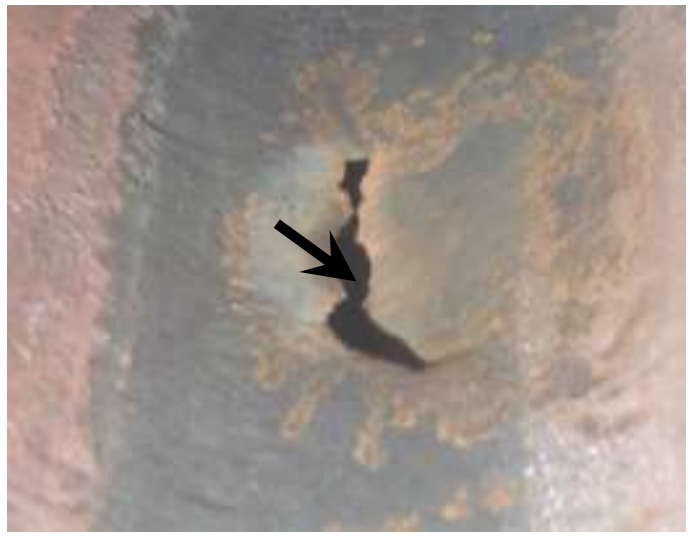

Gambar 4 : Foto kondisi visual di permukaan dalam pipa heater menunjukkan bahwa posisi pecahnya pipa tepat di area jam 6 dan permukaan dalam yang berwarna hitam cukup kasar (tidak rata).

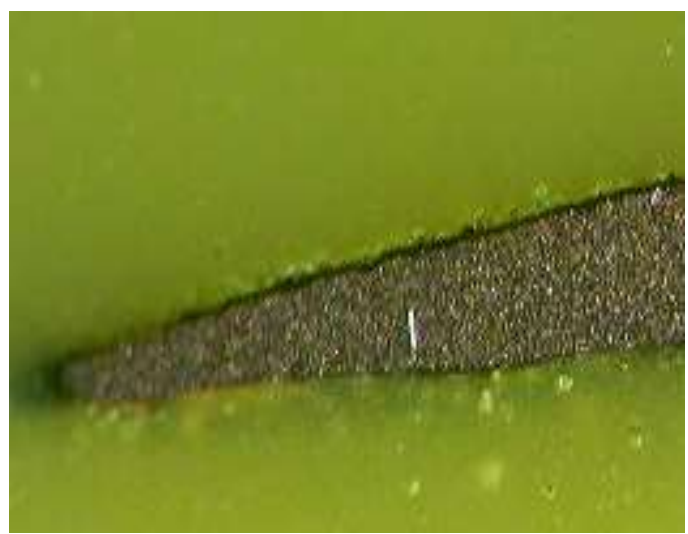


Gambar 5 : Foto makro sampel A, potongan melintang dari pipa yang pecah (rupture) terlihat jelas adanya indikasi penipisan dinding pipa dan pada ujung / bibir pecahan membentuk sudut permukaan yang tajam (tanda panah). Pembesaran 12X.

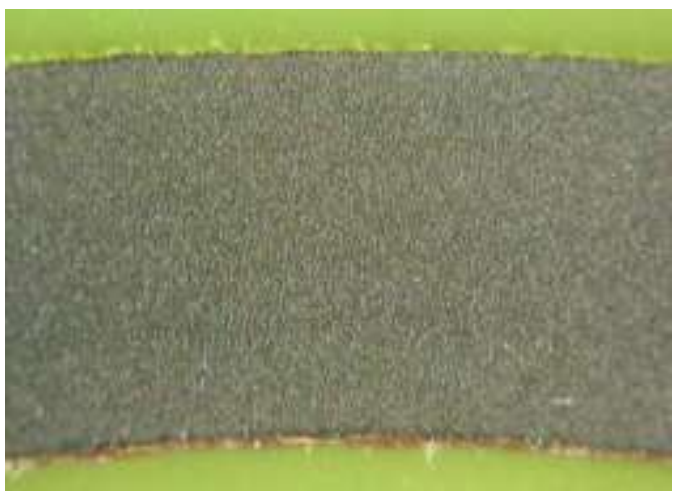

Gambar 6 :Foto makro sampel B,potongan melintang pada posisi jam 12 dari pipa heater tidak terlihat adanya indikasi penipisan dinding pipa. $6 \mathrm{X}$

\section{C.Pemeriksaan Ketebalan.}

Dari hasil pemeriksaan ketebalan pada pipa yang mengalami kerusakan seperti terlihat pada tabel 1 (lokasi pemeriksaan sangat dekat dengan pecah / robeknya pipa) menunjukkan bahwa ketebalan pipa di area jam 6 (area yang paling tipis) adalah sebesar $0,72 \mathrm{~mm}$, sedangkan ketebalan dinding pipa di area jam 12 adalah sebesar $6,25 \mathrm{~mm}$.

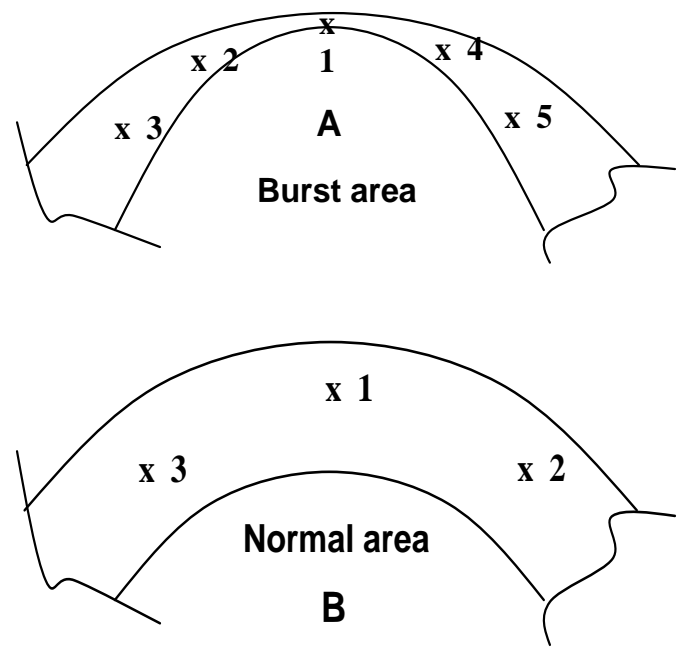

Tabel 1. Hasil pengukuran ketebalan pada pipa.

\begin{tabular}{ccc}
\hline \multirow{2}{*}{ No } & \multicolumn{2}{c}{ Thickness Value $(\mathrm{mm})$} \\
\cline { 2 - 3 } & Rupture Area & Normal Area \\
\hline 1. & 0.72 & 6.25 \\
\hline 2. & 1.87 & 6.28 \\
\hline 3. & 4.14 & 6.27 \\
\hline 4. & 1.96 & - \\
\hline 5. & 4.46 & - \\
\hline
\end{tabular}

\section{D.Pemeriksaan struktur mikro}

Dari hasil pemeriksaan struktur mikro (gambar 7 sampai dengan13) menunjukkan bahwa kondisi struktur mikro material pipa heatermasih sangat baik yaitu berupa normal ferit - pearlit,tidak terlihat adanya unsur-unsur atau senyawa-senyawa pengotor maupun cacat manufaktur (pabrikasi) lain di dalam struktur ${ }^{(6)}$.Namun demikian, pada foto struktur mikropermukaan potongan melintang di area bibir pecahnya pipa (gambar 7) terlihat adanya sedikit indikasi deformasi plastik di dalam struktur mikro. Dimana, bentuk struktur mikro material pipa yang semula berbentuk bulat dalam keadaan normal seperti terlihat pada gambar 8 atau gambar struktur mikro di area selain bibir pecahan pipa telah mengalami perubahan atau terdeformasi ke bentuk struktur mikro yang cendrung memanjang,tipis dan tajam ${ }^{(7)}$.

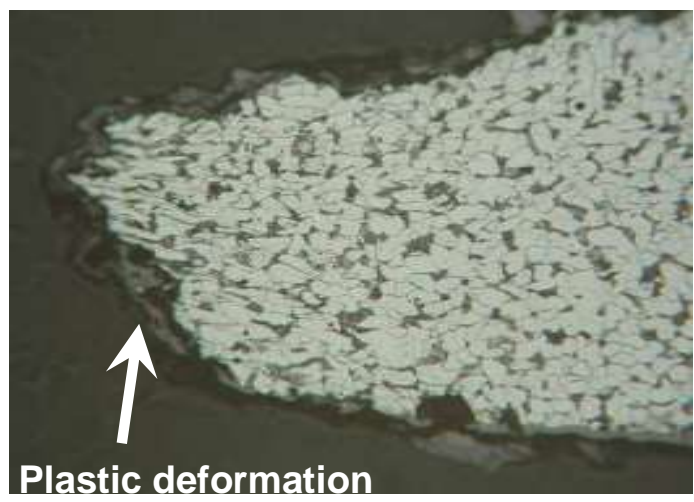

Gambar7 :Foto struktur mikro potongan melintang di bibir pecahan berupa normal ferit (putih) -pearlit (hitam) dan terlihat sedikit deformasi plastik di bibir pecahan. 100X. 


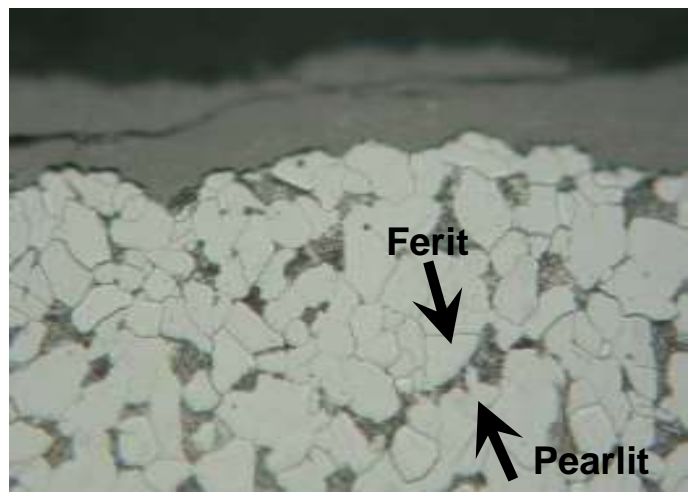

Gambar 8 :Foto struktur mikro material pipa di lokasi permukaan dalam sampel A berupa normal ferit-pearlit ${ }^{(8)}$ dan dipermukaannya terindikasi serangan korosi umum (general corrosion).200X.

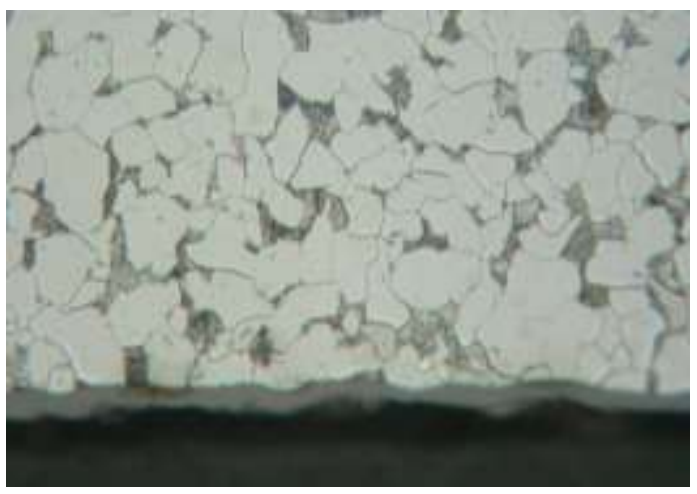

Gambar9 : Foto struktur mikro material pipa dipermukaan luar pada sampel A berupa normal ferit-pearlit dan terindikasi serangan korosi merata (uniform corrosion). 200X.

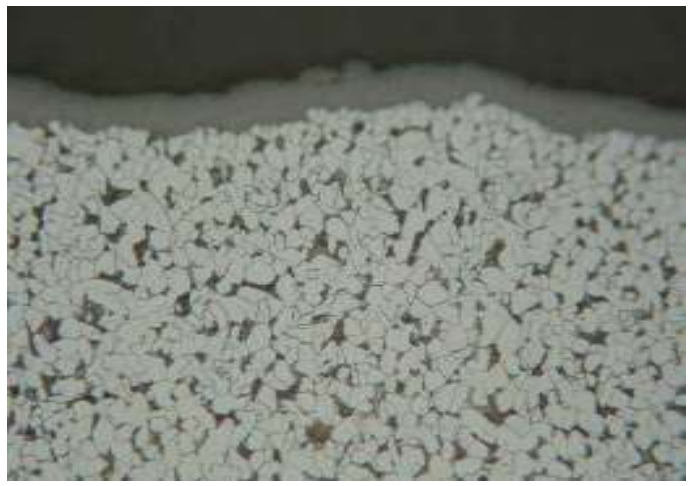

Gambar 10 : Foto struktur mikro material pipa pada area permukaan luar dari sampel $\mathrm{B}$ berupa normal ferit-pearlit dan terindikasi serangan korosi umum (general corrosion).100X.

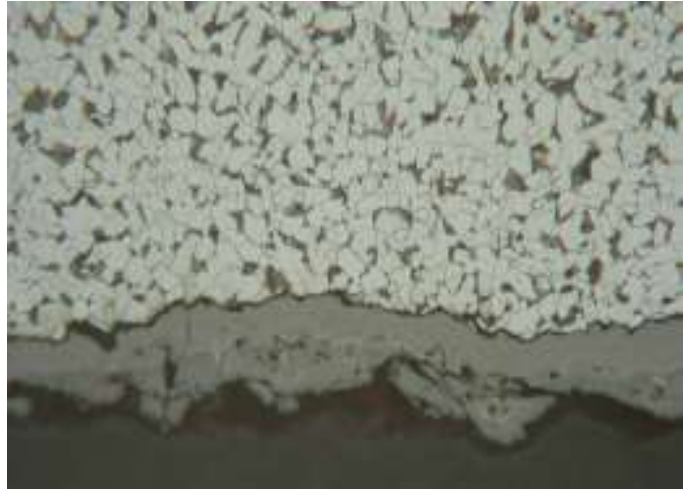

Gambar 11 : Foto struktur mikro pipa pada area permukaan dalam dari sampel B berupa normal ferit-pearlit dan terindikasi serangan korosi umum (general corrosion). $100 \mathrm{X}$.

\section{E. Pemeriksaan Fraktografi.}

Sedangkan dari hasil pemeriksaan SEM dipermukaan dalam pipa (di sekitar area pecah) menunjukkan bahwa kerusakan yang berupa penipisan dinding di dalam pipa tidak mengindikasikan sebagai pengaruh dari kecepatan aliran fluida karena dipermukaan tidak terlihat tanda adanya striation yang cukup signifikan. Analisa produk korosi di permukaan pipa dengan EDAX tidak terlihat adanya unsur-unsur yang sangat agresif, kecuali unsur oksigen yang merupakan media oksidator terhadap proses terjadinya korosi $^{(9)}$.

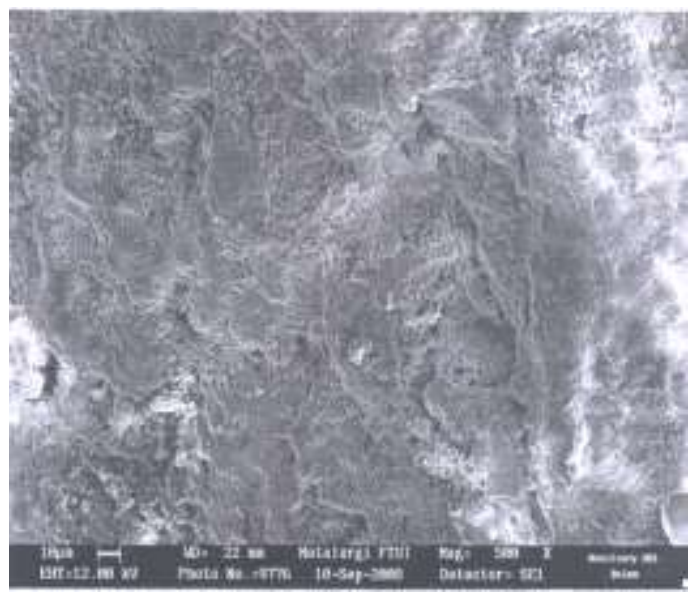

Gambar 12 :Foto fraktografi area permukaan dalam pipayang pecah menunjukkan bahwa pengaruh aliran fluida (terbentuknya striation di permukaan kontak) tidak signifikan. 




Gambar 13 : Hasil analisa kualitatif unsurunsur yang terkandung di permukaan pipa yang pecah dari hasil scanning dengan SEM-EDX

Tabel 2. Hasil analisa kuantitatif unsurunsur dipermukaan dalam pipa pecah.

\begin{tabular}{llrrr} 
Elmt & $\begin{array}{c}\text { Spect. } \\
\text { Type }\end{array}$ & \multicolumn{1}{c}{$\%$} & \multicolumn{1}{c}{$\%$} \\
C K K & ED & 9.10 & 19.92 \\
O K K & ED & 25.02 & 41.12 \\
Mg K K & ED & 1.61 & 1.74 \\
Al K & ED & 1.96 & 1.91 \\
Si K & ED & 3.24 & 3.03 \\
Ca K & ED & 24.08 & 15.80 \\
Fe K & ED & 34.98 & 16.47 \\
Total & & 100.00 & 100.00
\end{tabular}

\section{F. Uji Kekerasan}

Hasil uji kekerasan pada beberapa lokasi dari sampel pipaheater(tabel 3) menunjukkan bahwa perbandingan nilai kekerasan antara pipa di area pecah (rupture area) dengan di area normal tidak mengindikasikan adanya perbedaan yang cukup signifikan dan cendrung memiliki kesamaan nilai kekerasan.

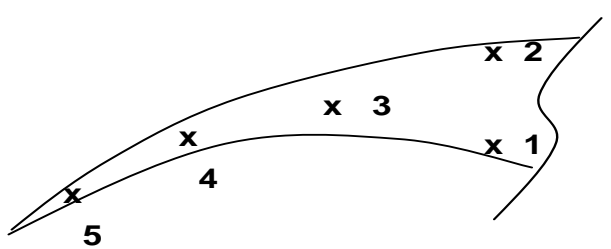

Sampel A

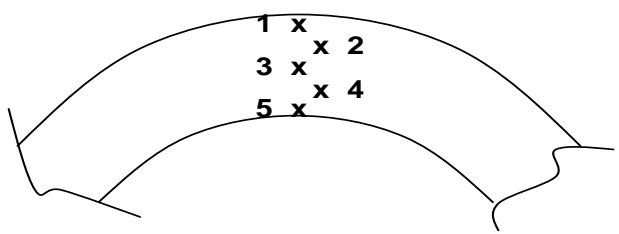

Sampel B

Tabel 3. Hasil uji kekerasan material pipa.

\begin{tabular}{ccc} 
No. & \multicolumn{2}{c}{ Hardness Value } \\
\cline { 2 - 3 } Lokasi & $\begin{array}{c}\text { Sampel A } \\
\text { (Area } \\
\text { Pecah) }\end{array}$ & $\begin{array}{c}\text { Sampel B } \\
\text { (Area Normal) }\end{array}$ \\
\hline 1. & 143 & 139 \\
\hline 2. & 138 & 141 \\
\hline 3. & 140 & 143 \\
\hline 4. & 143 & 137 \\
\hline 5. & 148 & 140 \\
\hline
\end{tabular}

\subsection{Pembahasan}

Berdasarkan hasil-hasil pemeriksaan terhadap pipa heater yang rusak menunjukkan bahwa kondisi fisik material pipa yang pecah telah mengalami penipisan sangat signifikan di posisi jam 6 (area pecah), namun kondisi struktur mikro pipamasih cukup baik.

Dengan nilai kekerasan minimum yaitu 138 HB yang diconversikan ke dalam nilai kekuatan dengan menggunakan persamaan $1^{(10)}$,maka diperoleh nilai kekuatan minimum sebesar $476 \mathrm{MPa}$. Dari hasil analisa komposisi kimia dan kekerasan material pipaheater tersebut dapat dinyatakan bahwa material sesuai dengan standar acuan yaitu ASTM A 106 grade $B$.

Tabel 5. Komposisi kimia standar ASTM A.106 Gr B ${ }^{(11)}$.

\begin{tabular}{cccc}
\hline $\begin{array}{c}\text { Unsu } \\
\mathbf{r}\end{array}$ & \% berat & $\begin{array}{c}\text { Unsu } \\
\mathbf{r}\end{array}$ & \% berat \\
\hline $\mathrm{C}$ & $0.30 \mathrm{max}$ & $\mathrm{Mo}$ & $0.15 \mathrm{max}$ \\
\hline $\mathrm{Si}$ & $0.10 \mathrm{~min}$ & $\mathrm{Cu}$ & $0.40 \mathrm{max}$ \\
\hline $\mathrm{Mn}$ & $0.29-1.06$ & $\mathrm{~V}$ & $0.08 \mathrm{max}$ \\
\hline $\mathrm{Cr}$ & $0.40 \mathrm{max}$ & $\mathrm{S}$ & $0.035 \mathrm{max}$ \\
\hline $\mathrm{Ni}$ & $0.40 \mathrm{max}$ & $\mathrm{P}$ & $0.035 \mathrm{max}$ \\
\hline
\end{tabular}

$\mathrm{Ts}=3,45 \times \mathrm{HB} \quad(\mathrm{MPa})$

$\mathrm{Ts}=$ Tensile strenght 


\section{HB = Hardness Brinell}

Pengamatan visual dan makro di sekitar area pecah mengindikasikan bahwa pengaruh tekanan operasi terhadap karakteristik kerusakan pipaheater tidak terlihat sangat signifikan karena deformasi plastik yang terbentuk dipermukaan pecahnya pipaheater tidak terlihat sangat signifikan.Dan hasil pengamatan dengan SEM (di sekitar area pecah) dipermukaan dalam pipayang mengalami penipisan juga tidak memperli-hatkan adanya pengaruh dari kecepatan aliran fluida.Oleh karena itu dapat dinyatakan bahwa kerusakan pipaheater tidak dipengaruhi oleh tekanan dan kecepatan aliran fluida.

Berdasarkan hasil perhitungan dengan menggunakan persamaan $2^{(12)}$, maka untuk pipa dengan ketebalan $6,25 \mathrm{~mm}$, diameter $101,87 \mathrm{~mm}$ dan tekanan kerja sebesar 28 $\mathrm{kgf} / \mathrm{cm} 2$ akan diperoleh nilai kekuatan yang terjadi di area tersebut sebesar 114,09 $\mathrm{kgf} / \mathrm{cm} 2$. Dan untuk pipadengan ketebalan minimum $0,72 \mathrm{~mm}$ dengan kondisi operasi yang sama, maka akan diperoleh nilai kekuatan yang terjadi di area tersebut sebasar 990,40 kgf/cm2. Sedangkan nilai kekuatan spesifikasi material sesuai dengan A 106 grade B adalah minimum 425 MPa.Hal ini membuktikan bahwa kondisi pipaheater yang mengalami pecah karena penipisan dinding pipayang sangat signifikan.

$\sigma=\frac{\mathrm{PD}_{\mathrm{o}}}{4 \mathrm{t}}$

Oleh sebab itu, dengan adanya bukti bahwa permukaan pipaheater yang pecah merupakan karakteristik dari retak/patah ulet (ductile) dan deformasi yang terbentuk sangat kecil, maka proses pecahnya pipadiperkirakan sangat cepat atau seketika yang disebabkan oleh kekuatan dari dalam pipayang cukup besar atau melebihi kekuatan material itu sendiri ( $\geq$ $475 \mathrm{kgf} / \mathrm{mm} 2$ ). Fenomena kerusakan seperti ini biasa disebut sebagai fenomena over load yang disebabkan oleh adanya kekuatan yang bekerja dari dalam pipayang melebihi kekuatan materialnya sendiri akibat adanya penipisan dinding tube.Dengan demikian penipisan dinding pipamerupakan penyebab terjadinya kerusakan berupa pecahnya dinding tube.

Adanya bukti bahwa pengaruh aliran dan tekanan operasi terhadap penipisan dinding pipadi area jam 6 tidak cukup signifikan, maka penipisan dinding pipadapat dipastikan terjadi akibat kapitasi dari gelembung uap air yang pecah karena posisi pipayang horizontal dan area tersebut merupakan area perubahan air menjadi uap (bubble point). Hal ini dapat dibuktikan dengan adanya batas penipisan yang dimulai dari jam 4.30 hingga 7.30 dan proses terjadinya kerusakan seperti ini sangat erat kaitannya dengan debit air atau level air yang masuk (water inlet) dan temperatur operasi yang mencapai $395{ }^{\circ} \mathrm{C}$.

\section{KESIMPULAN}

Dari hasil pemeriksaan dan pembahasan bahwa Kerusakan material pipa heater bukan disebabkan oleh faktor kegagalan material karena material sesuai dengan spesifikasi acuan yaitu ASTM A 106 grade $B$, ketebalan pipa di area normal masih cukup memadai dan dalam struktur mikro material tidak ditemukan unsur-unsur pengotor, cacat manufaktur maupun cacat lain yang dapat menyebabkan kerusakan. Kerusakan material pipaheater di awali dengan terjadinya penipisan yang sangat signifikan di area jam 4.30 hingga 7.30 akibat kapitasi dari gelembung uap air karena area tersebut merupakan area transisi dari air menjadi uap dan terjadinya kapitasi di area penipisan tersebut sangat erat kaitannya dengan susunan pipayang horizontal, debit air atau level air yang terjadi dan temperatur yang cukup memadai yaitu $395{ }^{\circ} \mathrm{C}$ serta untuk mencegah terjadinya kerusakan yang sama, maka pastikan proses terjadinya air menjadi uap setelah atau sebelum pipayang berhadapan langsung dengan sumber panas dengan meningkatkan atau menurunkan debit air atau level air atau dapat juga dilakukan dengan menurunkan temperatur.

\section{DAFTAR PUSTAKA}

1. Timothy Hill, Koch Refining, Pine Bend, MN, 2010, Journal "Heater Tube Life Management", National Petroleum Refiners Association Plant Maintenance Conference, May 22-25

2. Helmut Thielsch,"Defects and Failures in Pressure Vessels and Piping", Publising by Robert E. Krieger, Malabar, Florida. 7-11. 2009 
3. Francis Wildy,"Fire heater optimation", AMETEK process Instruments, Freeport Road Pittsburgh. 2009

4. R. E. Smallman, CBE, DSc, FRS, FREng, FIM And R. J. Bishop, PhD, CEng, MIM, "Modern Physical Metallurgy and Materials Engineering", Science, process and applications, Sixth Edition, Reed Educational and Professional Publishing Ltd 1995, 168-181.2010

5. W. R. Warke, "Failure Analysis And Prevention",Stress-Corrosion Cracking, ASM Handbook, Vol.9, 1810. 2011

6. Colangelo and Heiserc, "Analysis of Metalurgical Failures", Jhon Wiley \& Son Inc, New York, p12.81-84. 2009

7. Bruce L. Bramfitt, "Carbon And Alloys Steel", Handbook of Materials Selection Edited by Myer Kutz, JOHN Wiley \& Sons inc, New York, p 32 - 36. 2012

8. ..."Metallographyand Microstructures”, ASM Handbook, Vol.9, 2435, 2686,2010
9. William C. Leslie, "The Physical Metallurgy of Steels", Mc-GrawHill Company, Bruce L. Bramfitt, "Carbon And Alloys Steel", Handbook of Materials Selection Edited 185, 14-17. 2009

10. .....," Corrosion", Introduction, ASM Handbook, Vol.13, 11, 33. 2011

11. George E. Dieter, "Mechanical Metallurgy", SI Metric Edition, McGraw-Hill, 289. 2012

12. ....."FerrousMaterial Specifications", Materials, ASME ॥ Part A, ASME Boiler \& Pressure Vessel Code, New York, 205 - 219. 2009

13. G Antaki, "Piping And Pipeline Engineering", Design, Construction, Maintenance, Integrity And Repair, Marcel Dekker. 2011 